Fatima Angela C. Umali, MD

Antonio H. Chua, MD

Department of Otorhinolaryngology

Head and Neck Surgery

Jose R. Reyes Memorial Medical Center
Correspondence: Dr. Antonio H. Chua

Department of Otorhinolaryngology - Head and Neck Surgery 4th Floor, Jose R. Reyes Memorial Medical Center

Rizal Avenue, Sta. Cruz, Manila 1003

Philippines

Phone: (+632) 7119491 local 320

Email:entjrrmmc@yahoo.com

The authors declared that this represents original materia that is not being considered for publication or has not been published or accepted for publication elsewhere in full or in part, in print or electronic media; that the requirements for authorship have been met by all the authors, and that each author believes that the manuscript represents honest work.

Disclosures: The authors signed a disclosure that there are no financial or other (including personal) relationships, intellectual passion, political or religious beliefs, and institutional affiliations that might lead to a conflict of interest.

Presented at the Philippine Society of Otolaryngology Head and Neck Surgery Analytical Research Contest (3rd Place), November 17, 2016, Bella Ibarra, Quezon Avenue, Quezon City.

\section{Ehretia Microphylla (Tsaang Gubat) versus Loratadine as Treatment for Allergic Rhinitis: A Randomized Controlled Trial}

\begin{abstract}
Objective: To determine if Ehretia microphylla (Tsaang Gubat) decoction tea and placebo can improve the symptoms of mild intermittent allergic rhinitis in comparison to loratadine and control tea.
\end{abstract}

\section{Methods:}

Design: Double-Blind, Randomized Controlled Trial

Setting: $\quad$ Tertiary-Government Training Hospital

Participants: Twenty-four patients diagnosed with mild intermittent allergic rhinitis from October 2015 to July 2016 were randomly divided into a treatment group given Ehretia microphylla (Tsaang Gubat) decoction tea and placebo, and a control group given control tea and loratadine, both taken for 7 days. Patients underwent pre- and post-intervention evaluation by anterior rhinoscopy, Sino-nasal Outcome Test 22 (SNOT 22) Questionnaire and 10-point Visual Analog Scale (VAS). Data were encoded and subjected to statistical analysis using Mann Whitney $\mathrm{U}$ test and Wilcoxon Signed Rank test.

Results: Age and gender of the treatment and control group participants were comparable. Prior to intervention, no differences in symptoms were noted between both groups on SNOT 22 and VAS scores. After intervention, no differences in symptoms were noted between the 2 groups on SNOT 22 and VAS scores either. Comparison of pre- $(30.4 \pm 17.3)$ and post- $(7.2 \pm 6.5)$ intervention mean SNOT 22 scores of the loratadine control group with pre- $(32.5 \pm 23.7)$ and post- $(7.8 \pm 10.4)$ intervention mean SNOT 22 scores of the Ehretia Microphylla treatment group showed significant improvement of symptoms in both groups. Likewise, comparison of pre- and post-intervention mean VAS scores of the loratadine control group and pre- and post-intervention mean VAS scores of the Ehretia Microphylla treatment group based on symptoms of sneezing, rhinorrhea, nasal congestion and pruritus showed significant improvement of symptoms in both groups ( $p$-values of $<.001)$.

Conclusion: Ehretia microphylla (Tsaang Gubat) decoction tea may improve symptoms of allergic rhinitis (sneezing, rhinorrhea, pruritus and nasal congestion) and be taken as an alternative to loratadine in patients with mild intermittent allergic rhinitis. Further clinical trials with more participants may provide stronger evidence for this conclusion.

Keywords: Allergic rhinitis, tsaang gubat, ehretia microphylla, loratadine 
Allergic rhinitis is a common health problem affecting all ages with prevalence of $20 \%$ among Filipino adults.' Patients present with symptoms of sneezing, rhinorrhea, nasal congestion and pruritus. These symptoms result from the inflammatory reaction caused by the interplay of inflammatory cells and mediators due to exposure to allergens. Current treatment guidelines include recommendations for environmental modifications, antihistamines, decongestants, intranasal cromolyn, intranasal anti-cholinergics, intranasal corticosteroids and immunotherapy. ${ }^{2}$ Allergic rhinitis carries the burden of impaired quality of life and enormous cost implications. ${ }^{3}$ Thus, treatment goals focus on alleviating troublesome symptoms of allergic rhinitis at a viable economical cost.

Ehretia microphylla (Tsaang Gubat) is 1 of the 10 medicinal plants approved by the Republic of the Philippines Department of Health to treat different ailments. ${ }^{4}$ The leaves are traditionally used for medicinal purposes as an anti-spasmodic, mouthwash and body cleanser, attributed to the effects of different components (phenolic acids, flavonoids, benzoquinones, cyanogenetic glycosides, and fatty acids). ${ }^{5}$ It also contains rosmarinic acid and nitrile glucosides which are antiallergic substances that counter histamine release from mast cells that cause type-1 reactions., 5 Unfortunately, to the best of our knowledge, there is still no study detailing the use of this herbal medicine for allergic rhinitis. A PubMED, EMBASE and HERDIN search of the English literature using the keywords "allergic rhinitis," "tsaang gubat," "ehretia microphylla," and "loratadine" did not yield any study on the use of Ehretia microphylla for allergic rhinitis.

This study aims to determine if Ehretia microphylla (Tsaang Gubat) decoction tea and placebo can improve the symptoms of allergic rhinitis in comparison to loratadine and control tea.

\section{METHODS}

With Institutional Review Board approval, this double blind, randomized controlled trial was conducted at the Ear, Nose, Throat - Head and Neck Surgery (ENT-HNS) Out-Patient Department of the Jose R. Reyes Memorial Medical Center, a tertiary government training hospital from October 2015 to July 2016.

\section{Participants}

The target population were patients aged 18 years old and above who complained of sneezing, rhinorrhea, nasal congestion and pruritus; with pale, edematous, boggy mucosa on anterior rhinoscopy; clinically diagnosed with mild intermittent allergic rhinitis (symptoms $<4$ times per week or for $<4$ weeks, with normal sleep, and no impairment in daily activities, sport, leisure, work or school). Excluded were patients with nasal mass, polyp and nasal trauma, those with history, symptoms or signs of Ehretia microphylla allergy, and those who could not tolerate ingestion of the tea decoction.

\section{Preparation of Ehretia microphylla (Tsaang Gubat) decoction tea ${ }^{7}$}

Fresh leaves were gathered from Baliuag, Bulacan and authenticated at the University of Santo Tomas - Research Center for Natural and Applied Sciences Herbarium. After washing the leaves thoroughly in running water, one cup ( $200 \mathrm{ml}$ ) of leaves was chopped and boiled per 2 cups ( $400 \mathrm{ml}$ ) of water for 15 to 20 minutes under low heat. The boiled leaves were drained, cooled, transferred to clean plastic containers and refrigerated. The Ehretia Microphylla tea was given to participants in $1 \mathrm{~L}$ bottles that were refilled every 2 days during the study.

\section{Preparation of control tea}

One (1) teabag of Lipton Yellow Label Tea (Uniliver, Manila) was soaked per 2 cups ( $400 \mathrm{ml}$ ) of water just off the boil for 3 to 5 minutes. The teabag was removed and the tea preparation cooled, transferred to clean plastic containers and refrigerated. The control tea was given to participants in $1 \mathrm{~L}$ bottles that were refilled every 2 days during the study.

\section{PROCEDURE}

Clinical histories were obtained and physical examinations, including anterior rhinoscopy were performed by ENT-HNS resident physicians on duty. Each patient was asked to answer the Allergic Rhinitis Questionnaire ${ }^{2}$ as guide for fulfilling inclusion criteria. After obtaining informed consent 24 participants fulfilling these criteria were considered for inclusion in the study. Subjects were assigned to either of the 2 groups via electronic randomizer using Microsoft Excel for Mac 2011, Version 14.5.6 (150930) (Microsoft Corp., Redwood CA, USA).

The treatment group was given Ehretia microphylla tea taken by cupful (200 ml) every 4 hours when awake and placebo (flour dummy pill) taken once nightly, for 7 days. The control group was given loratadine $10 \mathrm{mg}$ / tablet taken once nightly and control tea taken by cupful (200 ml) every 4 hours when awake, also for 7 days.

The Sino-nasal Outcome Test 22 (SNOT22) Questionnaire (Washington University, St. Louis, Missouri) and 10-point Visual Analog Scale (VAS) scores per symptom of sneezing, rhinorrhea, nasal congestion and pruritus were obtained before and after intervention by the blinded outpatient resident physician on duty. Data were encoded and tallied in SPSS version 24 (IBM, 64 bit edition). Statistical analysis of different variables, mean and standard deviation were computed and analyzed using Mann Whitney $\mathrm{U}$ test, and Wilcoxon Signed Rank test, and $p$-values were set with $95 \%$ confidence interval. 


\section{ORIGINAL ARTICLES}

\section{RESULTS}

Twenty four participants, 11 males (45.8\%) and 13 females (54.2\%) with mean age of 44 years (range 18-77) were randomly assigned to two groups of 12 persons each and completed the study with no adverse events reported. There were no significant differences in age and gender between treatment and control groups.

Comparison of scores of individual SNOT 22 items between groups showed that there were no significant differences in symptoms before and after intervention. (Table 1, 2)

Comparison of mean SNOT 22 scores pre- $(30.4 \pm 17.3)$ and postintervention $(7.2 \pm 6.5)$ in the loratadine control group with mean SNOT

Table 1. Comparison of the Pre-Intervention SNOT 22 Between the Two Groups

\begin{tabular}{|c|c|c|c|}
\hline \multirow{2}{*}{ SNOT 22} & \multicolumn{3}{|c|}{ PRE-INTERVENTION } \\
\hline & $\begin{array}{c}\text { Control Group } \\
(n=12)\end{array}$ & $\begin{array}{l}\text { Treatment Group } \\
\qquad(\mathrm{n}=12)\end{array}$ & p-value \\
\hline 1. Need to blow nose & 2 & 2 & $.68(\mathrm{NS})$ \\
\hline 2. Sneezing & 4 & 4 & 1.00 (NS) \\
\hline 3. Runny nose & 3.5 & 4 & $.44(\mathrm{NS})$ \\
\hline 4. Cough & 1 & 1.5 & $.56(\mathrm{NS})$ \\
\hline \begin{tabular}{|l} 
5. \\
$\begin{array}{l}\text { Post-nasal } \\
\text { discharge }\end{array}$
\end{tabular} & 1 & 1 & $.88(\mathrm{NS})$ \\
\hline $\begin{array}{ll}\text { 6. } & \text { Thick nasal } \\
\text { discharge }\end{array}$ & 0.5 & 1 & .69 (NS) \\
\hline 7. Ear fullness & 1 & 1 & .86 (NS) \\
\hline 8. Dizziness & 1 & 1 & .74 (NS) \\
\hline 9. Ear pain/pressure & 0.5 & 0.5 & $.78(\mathrm{NS})$ \\
\hline 10. Facial pain/pressure & 0.5 & 0.5 & .98 (NS) \\
\hline $\begin{array}{l}\begin{array}{l}\text { 11. Difficulty falling } \\
\text { asleep }\end{array} \\
\end{array}$ & 1 & 1 & .90 (NS) \\
\hline 12. Wake up at night & 0 & 1 & .44 (NS) \\
\hline $\begin{array}{l}\text { 13. Lack of a good } \\
\text { night's sleep }\end{array}$ & 0 & 1 & .65 (NS) \\
\hline 14. Wake up tired & 0 & 0 & .78 (NS) \\
\hline $\begin{array}{l}\begin{array}{l}\text { 15. Fatigue during the } \\
\text { day }\end{array} \\
\end{array}$ & 0 & 0.5 & $.66(\mathrm{NS})$ \\
\hline \begin{tabular}{|l|}
$\begin{array}{l}\text { 16. Reduced } \\
\text { productivity }\end{array}$ \\
\end{tabular} & 0 & 0.5 & $.73(\mathrm{NS})$ \\
\hline $\begin{array}{l}\text { 17. Reduced } \\
\text { concentration }\end{array}$ & 0 & 0 & .71 (NS) \\
\hline $\begin{array}{l}\text { 18. Frustrated/restless/ } \\
\text { irritable }\end{array}$ & 1 & 0.5 & .44 (NS) \\
\hline 19. Sad & 1 & 0.5 & .44 (NS) \\
\hline 20. Embarrassed & 0.5 & 0 & .55 (NS) \\
\hline 21. Sense of smell/taste & 0 & 0 & .97 (NS) \\
\hline \begin{tabular}{|l|} 
22. Congestion/ \\
Obstruction of nose
\end{tabular} & 3 & 4 & $.54(\mathrm{NS})$ \\
\hline
\end{tabular}

22 scores pre- $(32.5 \pm 23.7)$ and post- $(7.8 \pm 10.4)$ intervention in the Ehretia Microphylla treatment group showed significant improvement of symptoms in both groups ( $p=.002$ and $p=.017$, respectively) as shown in Table 3.

There were no significant differences in the pre-intervention VAS scores of both groups specifically for symptoms of sneezing, rhinorrhea, nasal congestion and pruritus as shown in Table 4. Likewise, there were no significant differences in the post-intervention VAS scores of both groups. There was significant improvement noted in the pre- and post-intervention VAS scores $(p=.002$ and $p=.003)$ for both groups as shown in Table 5.

Table 2. Comparison of the Post-Intervention SNOT 22 Between the Two Groups

\begin{tabular}{|c|c|c|c|}
\hline \multirow[b]{2}{*}{ SNOT 22} & \multicolumn{3}{|c|}{ POST-INTERVENTION } \\
\hline & $\begin{array}{c}\text { Control Group } \\
(n=12)\end{array}$ & $\begin{array}{l}\text { Treatment Group } \\
\qquad(\mathrm{n}=12)\end{array}$ & $p$-value \\
\hline 1. Need to blow nose & 0 & 0 & .95 (NS) \\
\hline 2. Sneezing & 1 & 1 & .57 (NS) \\
\hline 3. Runny nose & 1 & 0 & .18 (NS) \\
\hline 4. Cough & 1 & 1 & 1.00 (NS) \\
\hline $\begin{array}{l}\text { 5. Post-nasal } \\
\text { discharge }\end{array}$ & 0 & 0 & .89 (NS) \\
\hline $\begin{array}{l}\text { 6. Thick nasal } \\
\text { discharge }\end{array}$ & 0 & 0 & .69 (NS) \\
\hline 7. Ear fullness & 0 & 0 & .91 (NS) \\
\hline 8. Dizziness & 0 & 0 & 1.00 (NS) \\
\hline 9. Ear pain/pressure & 0 & 0 & .62 (NS) \\
\hline 10. Facial pain/pressure & 0 & 0 & .91 (NS) \\
\hline $\begin{array}{l}\text { 11. Difficulty falling } \\
\text { asleep }\end{array}$ & 0 & 0 & .32 (NS) \\
\hline 12. Wake up at night & 0 & 0 & .57 (NS) \\
\hline $\begin{array}{l}\text { 13. Lack of a good } \\
\text { night's sleep }\end{array}$ & 0 & 0 & .93 (NS) \\
\hline 14. Wake up tired & 0 & 0 & .93 (NS) \\
\hline $\begin{array}{l}\text { 15. Fatigue during the } \\
\text { day }\end{array}$ & 0 & 0 & 1.00 (NS) \\
\hline $\begin{array}{l}\text { 16. Reduced } \\
\text { productivity }\end{array}$ & 0 & 0 & .58 (NS) \\
\hline $\begin{array}{l}\text { 17. Reduced } \\
\text { concentration }\end{array}$ & 0 & 0 & 1.00 (NS) \\
\hline $\begin{array}{l}\text { 18. Frustrated/restless/ } \\
\text { irritable }\end{array}$ & 0 & 0 & .44 (NS) \\
\hline 19. Sad & 0 & 0 & .91 (NS) \\
\hline 20. Embarrassed & 0 & 0 & .51 (NS) \\
\hline 21. Sense of smell/taste & 0 & 0 & .95 (NS) \\
\hline $\begin{array}{l}\text { 22. Congestion/ } \\
\text { Obstruction of nose }\end{array}$ & 1 & 1 & .65 (NS) \\
\hline
\end{tabular}


ORIGINAL ARTICLES

Table 3. Comparison of the Pre- and Post-Intervention SNOT 22 Mean Scores

\begin{tabular}{l|l|c|c|c|c|}
\hline Mean SNOT 22 & \multicolumn{1}{|c|}{$\begin{array}{c}\text { Control Group } \\
(\mathrm{n}=12)\end{array}$} & $\begin{array}{c}\text { Treatment Group } \\
(\mathrm{n}=12)\end{array}$ & \\
\hline & Mean & SD & Mean & SD & p-value \\
\hline Pre & 30.4 & 17.3 & 32.5 & 23.7 & .843 (NS) \\
\hline Post & 7.2 & 6.5 & 7.8 & 10.4 & .671 (NS) \\
\hline p-value & \multicolumn{2}{|c|}{$.002(\mathrm{~S})$} & \multicolumn{2}{|c|}{$.017(\mathrm{~S})$} & \\
\hline
\end{tabular}

Table 4. Comparison of Pre- and Post-Intervention VAS Scores per Symptom of Allergic Rhinitis

\begin{tabular}{|c|c|c|c|c|c|c|}
\hline \multicolumn{7}{|c|}{ A. Sneezing } \\
\hline & \multicolumn{2}{|c|}{$\begin{array}{c}\text { Control Group } \\
(\mathrm{n}=12)\end{array}$} & \multicolumn{2}{|c|}{$\begin{array}{l}\text { Treatment Group } \\
(\mathrm{n}=12)\end{array}$} & \multirow[b]{2}{*}{ Mann-Whitney } & \multirow[b]{2}{*}{$p$-value } \\
\hline VAS & Mean & SD & Mean & SD & & \\
\hline Pre & 7.8 & 1.8 & 7.9 & 1.6 & 68.0 & 0.843 (NS) \\
\hline Post & 1.1 & 0.9 & 1.0 & 1.0 & 65.0 & 0.713 (NS) \\
\hline Wilcoxon & \multicolumn{2}{|c|}{3.075} & \multicolumn{2}{|c|}{3.078} & & \\
\hline$P$-value & \multicolumn{2}{|c|}{$.002(S)$} & \multicolumn{2}{|c|}{$.002(S)$} & & \\
\hline
\end{tabular}

\section{B. Rhinorrhea}

\begin{tabular}{|l|c|c|c|c|c|c|}
\hline \multicolumn{1}{|c|}{} & $\begin{array}{c}\text { Control Group } \\
(\mathrm{n}=12)\end{array}$ & \multicolumn{2}{|c|}{$\begin{array}{c}\text { Treatment Group } \\
(\mathrm{n}=12)\end{array}$} & & \\
\hline VAS & Mean & SD & Mean & SD & Mann-Whitney & $\boldsymbol{p}$-value \\
\hline Pre & 6.8 & 1.4 & 7.2 & 1.2 & 58.5 & $.443(\mathrm{NS})$ \\
\hline Post & 1.0 & 1.0 & 0.4 & 0.5 & 46.5 & $.143(\mathrm{NS})$ \\
\hline Wilcoxon & \multicolumn{2}{|c|}{$\mathbf{3 . 0 8 9}$} & \multicolumn{2}{|c|}{$\mathbf{3 . 1 4 0}$} & & \\
\hline P-value & \multicolumn{2}{|c|}{$.002(\mathrm{~S})$} & \multicolumn{2}{|c|}{$.002(\mathrm{~S})$} & & \\
\hline
\end{tabular}

\begin{tabular}{|c|c|c|c|c|c|c|}
\hline \multicolumn{7}{|c|}{ C. Nasal Congestion } \\
\hline & \multicolumn{2}{|c|}{$\begin{array}{c}\text { Control Group } \\
(\mathrm{n}=12)\end{array}$} & \multicolumn{2}{|c|}{$\begin{array}{l}\text { Treatment Group } \\
\qquad(\mathrm{n}=12)\end{array}$} & \multirow[b]{2}{*}{ Mann-Whitney } & \multirow[b]{2}{*}{$p$-value } \\
\hline VAS & Mean & SD & Mean & SD & & \\
\hline Pre & 6.1 & 2.5 & 6.7 & 2.3 & 61.5 & .551 (NS) \\
\hline Post & 1.2 & 1.0 & 1.1 & 1.2 & 68.5 & .843 (NS) \\
\hline Wilcoxon & \multicolumn{2}{|c|}{3.108} & \multicolumn{2}{|c|}{3.077} & & \\
\hline P-value & \multicolumn{2}{|c|}{$.002(S)$} & \multicolumn{2}{|c|}{$.002(S)$} & & \\
\hline
\end{tabular}

\section{Pruritus}

\begin{tabular}{|l|c|c|c|c|c|c|}
\hline \multicolumn{1}{|c|}{} & \multicolumn{2}{c|}{$\begin{array}{c}\text { Control Group } \\
(\mathrm{n}=12)\end{array}$} & $\begin{array}{c}\text { Treatment Group } \\
(\mathrm{n}=12)\end{array}$ & & \\
\hline VAS & Mean & SD & Mean & SD & Mann-Whitney & p-value \\
\hline Pre & 6.4 & 1.2 & 7.4 & 1.0 & 38.0 & .052 (NS) \\
\hline Post & 1.0 & 0.7 & 1.3 & 0.8 & 54.0 & .319 (NS) \\
\hline Wilcoxon & \multicolumn{2}{|c|}{$\mathbf{3 . 0 8 4}$} & \multicolumn{2}{|c|}{$\mathbf{3 . 0 7 2}$} & & \\
\hline P-value & \multicolumn{2}{|c|}{$.002(S)$} & \multicolumn{2}{|c|}{$.002(S)$} & & \\
\hline
\end{tabular}

Table 5. Comparison of the Pre- and Post-Intervention VAS Mean Scores

\begin{tabular}{|l|c|c|c|c|c|}
\hline \multicolumn{1}{|c|}{ Mean VAS } & \multicolumn{2}{c|}{$\begin{array}{c}\text { Control Group } \\
(\mathrm{n}=12)\end{array}$} & $\begin{array}{c}\text { Treatment Group } \\
(\mathrm{n}=12)\end{array}$ & \\
\hline & Mean & SD & Mean & SD & p-value \\
\hline Pre & 2.6 & 1.6 & 2.8 & 2.1 & $.713(\mathrm{NS})$ \\
\hline Post & 0.5 & 0.5 & 0.5 & 0.7 & $.514(\mathrm{NS})$ \\
\hline p-value & \multicolumn{2}{|c|}{$.002(\mathrm{~S})$} & \multicolumn{2}{|c|}{$.003(\mathrm{~S})$} & \\
\hline
\end{tabular}

\section{DISCUSSION}

In this randomized controlled trial, both Ehretia microphylla (Tsaang Gubat) decoction tea (plus placebo) and loratadine (plus control tea) improved the symptoms of allergic rhinitis. Comparison of the SNOT22 and VAS scores before and after the intervention both for the loratadine control group and Ehretia microphylla treatment group showed improvement in sneezing, rhinorrhea, nasal congestion and pruritus.

The leaves of Ehretia microphylla (Tsaang Gubat) have been investigated for their anti-inflammatory property. The active components, rosmarinic acid and nitrile glucosides ${ }^{5,6}$ are claimed to be anti-allergic substances that counter histamine release from mast cells, rosmarinic acid being one of the particularly active principles. Ehretia microphylla has been found useful in the treatment of different inflammatory ailments. ${ }^{7}$

Rosmarinic acid is a strong anti-inflammatory agent according to several studies. ${ }^{5,8} \mathrm{~A}$ study by Osakabe et al., found a significant increase in responder rates for itchy nose, watery eyes and total symptoms in patients with seasonal allergic rhinoconjunctivities supplemented with rosmarinic acid. ${ }^{9}$ A decrease in the number of neutrophils and eosinophils in the lavage fluid from the same patients was noted with no adverse events recorded. ${ }^{9}$

Improvement of symptoms of sneezing, rhinorrhea, nasal congestion and pruritus in allergic rhinitis may be attributed to the anti-inflammatory effect of rosmarinic acid, by inhibition of histamine release and inhibition of adhesion molecule, chemokine and eicosnoid synthesis. ${ }^{6,9}$ In a study by Oh, rosmarinic acid inhibited IgE production, histamine release, inflammatory cytokine production and COX-2 expression. ${ }^{10}$

This study has several limitations. Since tsaang gubat was not compared with loratadine alone (loratadine was combined with a tea), possible interactions of tea with loratadine and effects of tea on allergic rhinitis itself were not accounted for in this study. Moreover, tsaang gubat can be prepared in various concentrations and administered in various forms, none of which were accounted for in this trial. Tsaang 
gubat itself may vary in effect depending on where it is sourced (studies have shown such variation for other herbals). It is important to note that the possible active ingredient(s) in tsaang gubat that have anti allergic and anti inflammatory properties were not isolated and may be present in varying concentrations as well.

In conclusion, Ehretia microphylla (Tsaang Gubat) decoction tea may improve symptoms of allergic rhinitis (sneezing, rhinorrhea, nasal congestion and pruritus) and be taken as an alternative to loratadine in patients with mild intermittent allergic rhinitis. Further clinical trials with more participants may provide stronger evidence for this recommendation.

\section{ACKNOWLEDGEMENTS}

The authors would like to thank Dr. Samantha S. Castañeda, the research coordinator who prereviewed this paper, Mr. Fercy B. Cavan for the statistical analysis of data, and the JRRMMC ENT-HNS residents who helped in data gathering.

\section{REFERENCES}

1. Abong JM, Kwong SL, Alava HD, Castor MA, De Leon JC. Prevalence of allergic rhinitis in Filipino adults based on the National Nutrition and Health Survey 2008. Asia Pac Allergy. 2012 Apr;2(2):129-135. DOI: 10.5415/apallergy.2012.2.2.129. PMID: 22701863 PMCID: PMC3345326.

2. Bousquet J, Reid J, van Weel C, Baena Cagnani C, Canonica GW, Demoly P, et al. Allergic rhinitis management pocket reference 2008. Allergy. 2008 Aug;63(8):990-996. DOI: 10.1111/j.1398 9995.2008.01642.x. PMID: 18691301.

3. Green RJ, Davis G. The burden of allergic rhinitis. J Allergy Clin Immunol Current Allergy \& Clinical Immunology. 2005 Nov;18(4):176-178.

4. Ammakiw C, Odiem M. Availability, preparation, and uses of herbal plants in Kalinga, Philippines. Eur Sci J. 2013; 4:1857.

5. Simpol LR, Otsuka H, Ohtani K, Kasai R, Yamasaki K. Nitrile glucosides and rosmarinic acid, the histamine inhibitor from Ehretia philippinensis. Phytochemistry. 1994;36(1):91-95.

6. Yamamura S, Simpol LR, Ozawa K, Ohtani K, Otsuka H, Kasai R, et al. Antiallergic dimeric prenylbenzoquinones from Ehretia microphylla. Phytochemistry. 1995 May;39(1):105-110. PMID: 7786482.

7. Alvarez, AA. Tsaang Gubat or Wild Tea (Ehretia microphylla Lam.). [Retrieved 2015 Mar 6] Available from: http://www.philippineherbalmedicine.org/tsaang_gubat.htm.

8. Sanbongi C, Takano H, Osakabe N, Sasa N, Natsume M, Yanagisawa R, et al. Rosmarinic acid inhibits lung injury induced by diesel exhaust particles. Free Radic Biol Med. 2003 Apr 15; 34(8):1060-1069. PMID: 12684091.

9. Osakabe N, Takano H, Sanbongi C, Yasuda A, Yanagisawa R, Inoue K, et al. Anti-inflammatory and anti-allergic effect of rosmarinic acid (RA); inhibition of seasonal allergic rhinoconjunctivitis (SARS) and its mechanism. Biofactors. 2004;21(1-4):127-131. PMID: 15630183.

10. Oh HA, Park CS, Ahn HJ, Park YS, Kim HM. Effect of Perilla frutescens var. acuta Kudo and rosmarinic acid on allergic inflammatory reactions. Exp Biol Med. 2011 Jan; 236(1): 99-106. DOI: 10.1258/ebm.2010.010252. PMID: 21239739.

11. Farnsworth NR, Akerele O, Bingel AS, Soejarto DD, Guo Z. Medicinal plants in therapy. Bull World Health Organ. 1985;63(6): 965-981. 